\title{
The Variation of Structure and Transporting Property in $\mathrm{SrRu}_{1-\mathrm{x}} \mathrm{Fe}_{\mathrm{x}} \mathrm{O}_{3}$
}

\author{
Jung-Chul Park,; Don Kim, ${ }^{\dagger}$ Choong-Sub Lee, ${ }^{\ddagger}$ and Song-Ho Byeon ${ }^{\sharp}$ \\ Depantment of Hano Materials Science and Technologn. Hano Applied Technologe Reseanch Center: \\ Silla liniversin. Busam 617-730. Komea

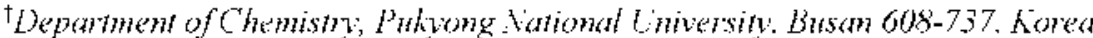

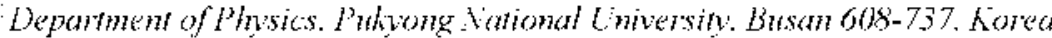

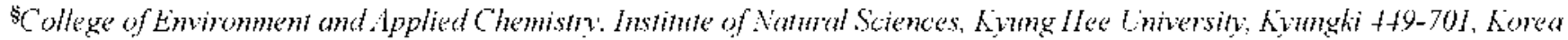 \\ Received Hay 24. 2002
}

Key Words : Fe-substituted SrRuO, Bond-lengths and bond angles, Resistance

The ruthenium based perovskite oxide. $\mathrm{SrRuO}_{3}$ has been intensively studied due to its diverse electronic and magnetic propertics. The structure of $\mathrm{SrRuO}_{3}$ is orthorhombic $(\mathrm{a}=$ $5.573 \dot{A}, b=5.538 \AA \mathrm{A}, \mathrm{c}=7.856 \AA \mathrm{A}$ ). which is similar to that of rare carth orthoferritc. $\mathrm{GdFeO}_{3}$, but it can be considered as pseudo-cubic $\left(a_{1}=3,93 \AA\right.$ A). Howcver. the electrical property of both compounds is contradictory to each oller. namely a good conductor for $\mathrm{SrRuO}_{3}$ and an insulator for $\mathrm{GdFcO}_{3}$. This might be due to the different electron configurations as $\mathrm{GdFeO}_{3}$ adopts the ligh spin $\mathrm{I}_{20}{ }^{3} \mathrm{e}_{0}{ }^{2}$ of $\mathrm{Fe}^{3+}$ and $\mathrm{SrRuO}_{3}$ the low spin $1_{2 \mathrm{~g}}{ }^{1} \mathrm{c}_{\mathrm{g}}{ }_{\mathrm{g}}$.' of $\mathrm{Ru}^{1-}$.

Recently. llic clectronic structural variation of $\mathrm{ARuO}_{3}$ (A $=\mathrm{Ca}$. Sr. and $\mathrm{Ba}$ ) las been discussed using X-ray pholoelectron spectroscopy. ultraviolet photoclectron spcciroscopy. and Riclveld fitting of the XRD data.' The ionic radii of A cations $(\mathrm{Ca}=1.3+\dot{A}, \mathrm{Sr}=1.4+\dot{A}$, and $\mathrm{Ba}=1.61 \dot{A})$ induces the distorted orthorhombic. particularly hexagonal symmety for $\mathrm{Ba}$ compound. Morcover. the variation in $\mathrm{Ru}-\mathrm{O}$ and $\mathrm{Ru}-\mathrm{Ru}$ bond distances has a great influence on the electrical and magnetic propertics of lliese compounds.

Some reports on the partial substitution of metal cations in $\mathrm{Ru}$ siles of $\mathrm{ARuO}_{3}$. ( $\mathrm{A}=\mathrm{Sr}$. Ca) have becn issucd. $\mathrm{SrTi}_{1-\mathrm{x}^{-}}$ $\mathrm{R}_{\mathrm{u}} \mathrm{O}_{\mathrm{i}-\delta}(0 \leq x \leq 1)$ depositcd films arc cubic or pscudocubic over the whole composition range with the lattice parameters increasing continuously with the concentration of Rut ${ }^{1-}$. which correspondingly results in the conductivity variation from insulating to metallic behavior. ${ }^{2}$ The magnetic and transport propertics of $\mathrm{CaMu}_{1-x} \mathrm{Ru}_{x} \mathrm{O}_{3}(0<x \leq 0.8)$ were studied by Maignan el al. using resistivity and ac-susceptibility measurements. and they cxplained that the inducement of ferromagnelism and metallicity in the antiferromagnetic $\mathrm{CaMnO}_{3}$ matrix is duc to the valence combination $\left(\mathrm{Ru}^{5-}\right.$ crealing $\mathrm{Mur}^{3+}$ ). which allows double cxchange through the lyybridization between Ru and Mn $\mathrm{c}_{\mathrm{r}}$ orbitals. ${ }^{3}$

As previously reported. $\mathrm{SrFCO}_{3-\mathrm{x}}(0 \leq x \leq 0,5)$ is particularly interesting because of not only the unusual oxidation state of $\mathrm{Fe}^{4-}$ but also the wide range of oxygen non-stoichiometry: Takano et al. reported that the $\mathrm{SrFeO}_{3-x}$ plases $(x=2.50$. 2.73. 2.86. and 3.00) exist in different structures. ${ }^{-1}$ The perovskite cell is cubic for $2.88 \leq x \leq 3.00$ and tetragonal (or orhorhombic) for $2.72 \leq x \leq 2.88$. I1 should be pointed oul that the $\mathrm{SrFeO}_{2}$ phase with brownillerite structure is shown to derive from the cubic $\mathrm{SrFeO}_{3}$ unil cell by periodic removal of $\mathrm{O}$ atoms ria [101] directions. Therefore. the solid-solution betwecn $\mathrm{SrRuO}_{3}$ and $\mathrm{SrFcO}_{3-\mathrm{x}}$ is of great interest as the ionic radius of the cations are quite similar (0.620 $\mathrm{A}$ for $\mathrm{Ru}^{1+} \cdot 0.645 \mathrm{~A}$ for $\mathrm{Fc}^{3+}$. and $0.585 \AA$ for $\left.\mathrm{Fe}^{1+}\right)^{5}$ and the different electronic configuration may have a great eflect on the transporting propertics of $\mathrm{SrRu}_{1-\mathrm{x}} \mathrm{Fc}_{\mathrm{x}} \mathrm{O}_{3}$. In the present paper. we explore the electronic and cry stal structure of $\mathrm{SrRu}_{1-\mathrm{x}} \mathrm{Fe}_{2} \mathrm{O}_{3}(0 \leq x \leq 0.5)$ in order to explain the variation of transporting propertics of Fc-substituted $\mathrm{SrRuO}_{3}$.

\section{Experimental Section}

The compounds in the $\mathrm{SrRu}_{-x} \mathrm{Fc}_{\mathrm{C}_{3}} \mathrm{O}_{3}(0 \leq x \leq 0.5)$ solid solution were prepared by typical solid state reactions. Well ground stoichiometric mixlures of $\mathrm{SrCO}_{3}$. $\mathrm{RuO}_{2}$. and $\mathrm{Fc}_{2} \mathrm{O}_{3}$ were healed at $900^{\circ} \mathrm{C}$ for $12 \mathrm{~h}$ in air. The ground residues were pelletized and heated at $1150^{\circ} \mathrm{C}$ for $2+\mathrm{h}$ in air. The final treatment was performed on pellets at $1200^{\circ} \mathrm{C}$ for $24 \mathrm{~h}$ in air.

The formation of a single phase was confinned by powder $\mathrm{X}$-ray diffraction (XRD). The patterns for stnucture refinement were recorded on a rotating anode installed diffraclomeler with an X-ray source of $40 \mathrm{kV}$. $300 \mathrm{~mA}$. The $\mathrm{Cu} \mathrm{K} \alpha$ radiation used was monochromated by a curred-crystal graphite. The data were collecled will a step-scan procedure in the range $2 \theta=20$ - $100^{\circ}$ with a siep width of $0.02^{\circ}$ and a step lime of $1 \mathrm{~s}$. The refinements of reflection positions and intensitics were carricd out using the Rictveld analysis program RIETAN (Izumi el al.. 1987). Mössbaucr spectroscopic studies were carricd oul at $300 \mathrm{~K}$ with $\mathrm{Co}^{57}$ source doped in metallic rhodium which was oscillated in a simusoidal mode. The Doppler velocily of spectra was calibrated with $\alpha$-Fe foil ( $25 \mu \mathrm{m}$ in thickness). The clectrical resistance of polycrystalline pellets was measured using a standard four probe method

\section{Results and Discussion}

XRD diffraction patterns of $\mathrm{SrRu}_{1-x} \mathrm{Fc}_{\mathrm{*}} \mathrm{O}_{3}(0 \leq x \leq 0.5)$ arc shown in Figures 1-2. The refined structural paranciers obtained from the Rictycld fitting of the XRD data are given 


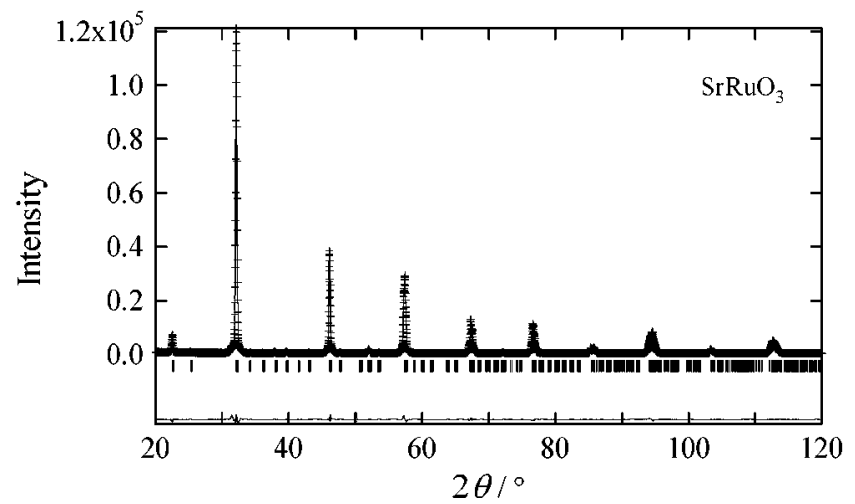

Figure 1. The experimental (top), fitted (middle), and difference (bottom) of X-ras diliraction pattem ol SrRuOs.

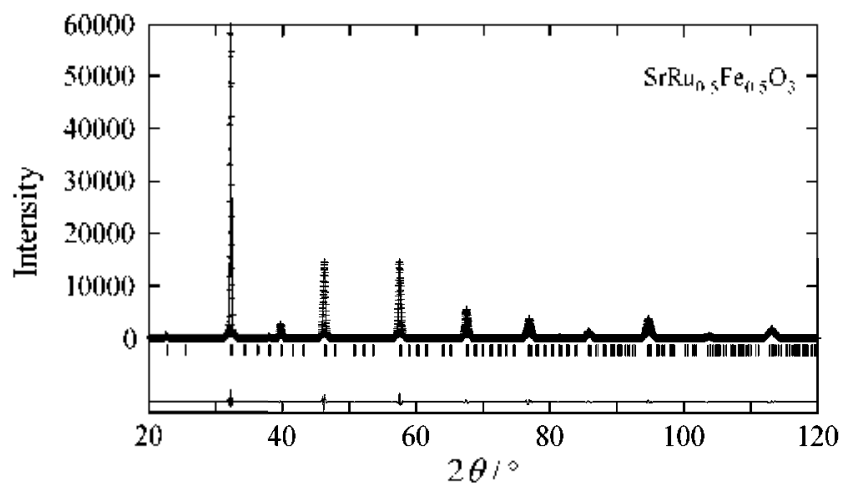

Figure 2. The experimental (lop). filled (middle), and dillerence (bottom) of X-ray diffraction patten of $\mathrm{StR} u_{0.5} \mathrm{Fe}_{0.6} \mathrm{O}_{3}$

Table 1. The structural parameters obtained from the Rictveld fitting of the XRD data

\begin{tabular}{|c|c|c|c|c|c|c|c|}
\hline \multirow{2}{*}{ Compounds } & \multicolumn{4}{|c|}{ Reliability factors $\left({ }^{0} 0\right)$} & \multicolumn{3}{|c|}{ Lattice parameters $(\AA)$} \\
\hline & $R_{1}$ & $R_{w}$ & $R_{\mathrm{P}}$ & $R_{\mathrm{T}}$ & $a$ & $h$ & $c$ \\
\hline istos & 1.78 & 8.84 & 5.4 & 2.89 & $57 t$ & (s) & $356(1)$ \\
\hline 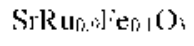 & 1.68 & 8.43 & 5.41 & 3.72 & 569 & 847 & $5359(1)$ \\
\hline SiRur.s] $\mathrm{e}_{0}=0$ & 1.09 & 8.08 & 5.23 & 3.89 & 5.568 & $x 34$ & $5374(1)$ \\
\hline 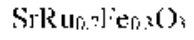 & 1.13 & 6.66 & 4.64 & 3.99 & .56 & $6-1$ & $5375(1)$ \\
\hline 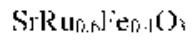 & 1.15 & 7.01 & 4.99 & 4.17 & 5.560 & 3.34 & $5426(2)$ \\
\hline 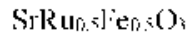 & 0.81 & 8.94 & 6.7 & 4.32 & .5475 & 80 & $5.549(4)$ \\
\hline
\end{tabular}

in Table 1 and the bond lengths and bond angles are listed in Table 2. The XRD data indicate that $\mathrm{SrRu}_{1-X} \mathrm{Fe}_{\mathrm{O}} \mathrm{O}_{3}$ are orthorhombically distorted $\mathrm{GdFeO}_{3}$ type stnicture with space group Pnma. Particularly: the lattice parameters, $a$ and $b$ gradually increase with increasing Fe-substitution. whereas the lattice parameter. $c$ decreases, as shown in Table l. In order to determine the valence state of $\mathrm{Fe}$. Mössbauer spectroscopy was used. As shown in Figure 3, the valence state of iron in $\mathrm{SrRu}_{1-\mathrm{F}} \mathrm{Fe}_{3} \mathrm{O}_{3}(x=0.1 .0 .2 .0 .3 .0 .4$, and 0.5$)$ is determined to be $\mathrm{Fe}$ (liI) with the isomer shifts. $\delta=0.24$. 0.26 .0 .27 .0 .28 . and $0.30 \mathrm{~mm} / \mathrm{s}$. respectively ${ }^{\text {fis }}$ As above mentioned, the magnetic and transport properties of the $\mathrm{CaMn}_{I_{-x}} \mathrm{Ru}_{x} \mathrm{O}_{3}(0<x \leq 0.8)$ were studied by Maignan $e^{2} t$ al.. ${ }^{*}$ and they explained that the inducement of ferromagnetism
Table 2. The bond lengths and bond angles obtained from the Rietveld data

\begin{tabular}{|c|c|c|c|c|}
\hline \multirow{2}{*}{$\begin{array}{l}\text { Compounds } \\
\mathrm{SrRuO}_{3}\end{array}$} & \multicolumn{2}{|c|}{ Bond length (A) } & \multicolumn{2}{|c|}{ Bond angle (deg) } \\
\hline & $\mathrm{Rll}-\mathrm{Ol}(\times 2)$ & $1.968(2)$ & Ru-Ol-Ru & $171.6(9)$ \\
\hline & $\mathrm{Rul}-\mathrm{O} 2(\times 2)$ & $1.991(9)$ & Ru-O2-Ru & $160.3(4)$ \\
\hline & $\mathrm{Rll}-\mathrm{O} 2(\times 2)$ & $1.994(9)$ & & \\
\hline \multirow[t]{3}{*}{$\mathrm{SrR} u_{0 .} \mathrm{Fe}_{0.1} \mathrm{O}_{3}$} & $\mathrm{RuFc}-\mathrm{Ol}(\times 2)$ & $1.964(2)$ & $\mathrm{RuFe}-\mathrm{Ol}-\mathrm{RuFe}$ & $172.1(9)$ \\
\hline & $\mathrm{RuFc}-\mathrm{O} 2(\times 2)$ & $1.972(9)$ & $\mathrm{RuFe}-\mathrm{O} 2-\mathrm{RuFe}$ & $162.4(4)$ \\
\hline & $\mathrm{RuFc}-\mathrm{O}_{2}(\times 2)$ & $2.001(9)$ & & \\
\hline \multirow[t]{3}{*}{$\mathrm{SrRul}{ }_{8} \mathrm{Fe}_{0.2} \mathrm{O}_{3}$} & $\mathrm{RuFc}-\mathrm{Ol}(\times 2)$ & $1.967(2)$ & RuFe-Ol-RuFe & $170.5(9)$ \\
\hline & $\mathrm{RuFc}-\mathrm{O}_{2}(\times 2)$ & $1.95(1)$ & $\mathrm{RuFe}-\mathrm{O} 2-\mathrm{RuFe}$ & $166.1(4)$ \\
\hline & $\mathrm{RuFc}-\mathrm{O}_{2}(\times 2)$ & $2010(9)$ & & \\
\hline \multirow[t]{3}{*}{$\mathrm{SrRu} \mathrm{F}_{0} \mathrm{Fe}_{0.3} \mathrm{O}_{3}$} & $\mathrm{RuFc}-\mathrm{Ol}(\times 2)$ & $1.967(2)$ & $\mathrm{RuFe}-\mathrm{Ol}-\mathrm{RuFe}$ & $169 .(9)$ \\
\hline & $\mathrm{RuFc}-\mathrm{O}_{2}(\times 2)$ & $1.95(1)$ & $\mathrm{RuFe}-\mathrm{O} 2-\mathrm{RuFc}$ & $168.2(3)$ \\
\hline & $\mathrm{RuFc}-\mathrm{O}_{2}(\times 2)$ & $2.00(1)$ & & \\
\hline \multirow[t]{3}{*}{$\mathrm{SrRu}_{\mathrm{n}} \mathrm{Fe}_{\mathrm{O}} \mathrm{O}_{3}$} & $\mathrm{RuFc}-\mathrm{Ol}(\times 2)$ & $1.978(2)$ & $\mathrm{RuFe}-\mathrm{Ol}-\mathrm{RuFc}$ & $163.7(8)$ \\
\hline & $\mathrm{RuFc}-\mathrm{O} 2(\times 2)$ & $1.96(2)$ & $\mathrm{RuFe}-\mathrm{O} 2-\mathrm{RuFc}$ & $169.8(5)$ \\
\hline & $\mathrm{RuFc}-\mathrm{O} 2(\times 2)$ & $1.98(2)$ & & \\
\hline \multirow[t]{3}{*}{$\mathrm{SrR}_{10}: \mathrm{FC}_{0}: \mathrm{O}_{3}$} & $\mathrm{RuFc}-\mathrm{O} \mid(\times 2)$ & $2,001(2)$ & $\mathrm{RuFe}-\mathrm{O} 1-\mathrm{RuFc}$ & $155.7(6)$ \\
\hline & $\mathrm{RuFc}-\mathrm{O} 2(\times 2)$ & $1.92(1)$ & $\mathrm{RuFc}-\mathrm{O} 2-\mathrm{RuFc}$ & $176.2(6)$ \\
\hline & $\mathrm{RuFc}-\mathrm{O}_{2}(\times 2)$ & $2.01(1)$ & & \\
\hline
\end{tabular}

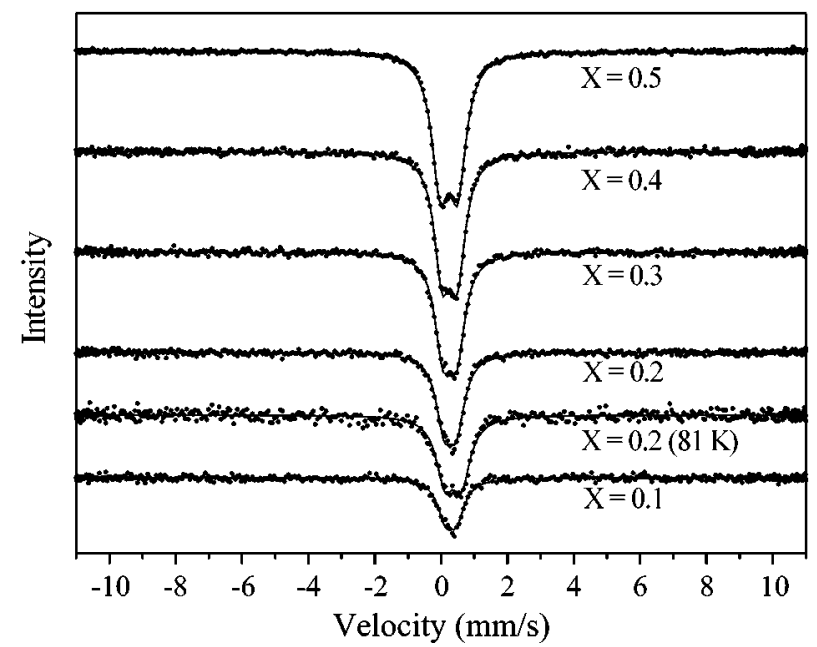

Figure 3. Mössbauler spectra of $\mathrm{SrRu}_{3-\mathrm{x}} \mathrm{Fe}_{\mathrm{x}} \mathrm{O}_{3}$ collected at room lemperalure and $81 \mathrm{~K}$.

and metallicity in the anti-ferromagnetic $\mathrm{CaMnO}_{3}$ matrix is due to the valence combination ( $\mathrm{Ru}^{51}$ creating $\mathrm{Mr}^{3}$ ). which allow's double exchange through the hybridization between $\mathrm{Ru}$ and $\mathrm{Mn} \mathrm{e}_{\mathrm{z}}$ orbital. In our system. as $\mathrm{Fe}^{3 .}$ species are introduced into the $\mathrm{SrRuO}_{\mathrm{i}}$ lattice according to the formula of $\mathrm{SrRul}^{+1}{ }_{1-2 \times} \mathrm{Rul}^{i 1}{ }_{x} \mathrm{Fe}^{31}{ }_{\times} \mathrm{O}_{3}, \mathrm{Ru}^{i 1}$ species are formed. So, the local symmetry of (Ru.Fe) $\mathrm{O}_{i}$ octahedra including (Ru.Fe)-O bond lengths and (Ru,Fe)-O-(Ru,Fe) bond angles may be considerably different from that of $\mathrm{RuO}_{4}$ ones. The $\mathrm{SrRuO}_{3}$ compound has a structure derived from the cubic perovskite stnicture. In this stnucture. the tolerance factor. $t=\left(R_{\mathrm{si}}{ }^{21}+\right.$ $\left.R_{0-}\right) / \sqrt{2}\left(R_{\mathrm{Ru}^{+1}}+R_{\mathrm{i}}-\right)$ which relates the $\mathrm{Sr}-\mathrm{O}$ and $\mathrm{Ru}-\mathrm{O}$ bond lengths. represents ideal bond-length matching for $t$ $=1$. A $t \approx 1$ at high temperature results in a $t<1$ at lower temperature. A $t<1$ place the $\mathrm{Ru}-\mathrm{O}$ bonds under com- 


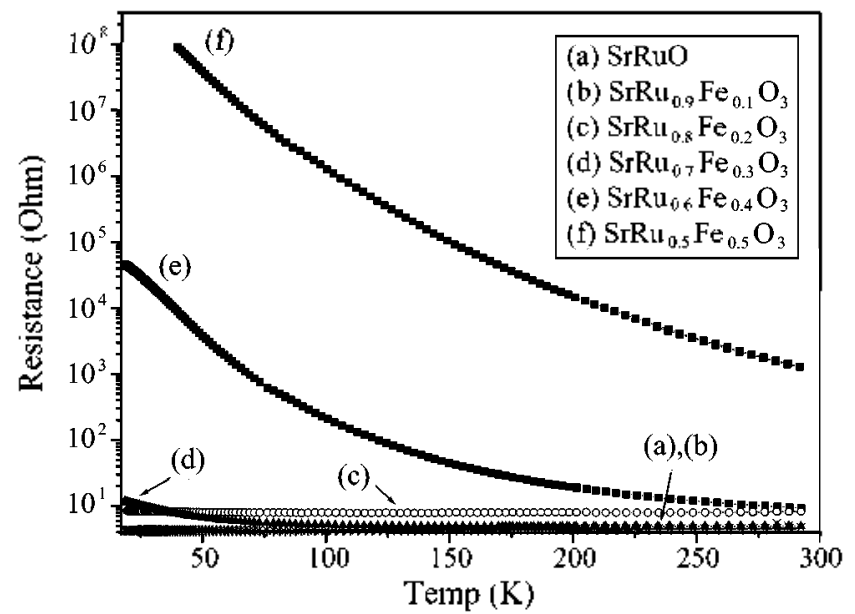

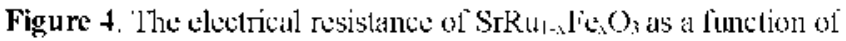
temperature

pression and $\mathrm{Sr}-\mathrm{O}$ bonds under tension. This incompatibility can be relieved by a cooperative rotation of the $\mathrm{RuO}_{6}$ octahedrat that bends the Ru-O-Ru bond. As listed in Table 2. the $\mathrm{SrRu}_{1-\mathrm{S}} \mathrm{Fe}_{\mathrm{x}} \mathrm{O}_{3}$ compounds has different bond lengths. in particular $(\mathrm{Ru} . \mathrm{Fe})-\mathrm{O}_{1}(\times 2)=2.00 \mathrm{~A} .(\mathrm{Ru} . \mathrm{Fe})-\mathrm{O}_{2}(\times 2)=1.92$ A. and $(\mathrm{Ru} . \mathrm{Fe})-\mathrm{O}_{2}(\times 2)=2.01 \mathrm{~A}$ for $\mathrm{SrRll}_{1} \mathrm{Fe}_{1,5} \mathrm{O}_{3}$ compound. which discloses that the $\mathrm{Fe}^{3 .}$ species create $\mathrm{Rll}^{5}$ species as the longer $(2.01 \mathrm{~A})$ and the shorter bond-length $(1.92 \mathrm{~A}$ ) exist in ( $\mathrm{Ru} . \mathrm{Fe})-\mathrm{O}$ 2 sheets compared with those of $\mathrm{SrRuO}_{3}$. It should be pointed out that the ( $\left.\mathrm{Ru} . \mathrm{Fe}\right)-\mathrm{O}_{2}$ bond lengths manifest the strength of hybridization between $\mathrm{Ru}$ td and $\mathrm{O} 2 \mathrm{p}$ states. which is correlated with the transport properties of these compounds. Moreover. the (Rul, Fe)- $\mathrm{O}_{1}$ (Ru.Fe) bond angles are contimuously decreased with increasing the contents of $\mathrm{Fe}$. whereas (Ru, $\mathrm{Fe})-\mathrm{O}_{2}-(\mathrm{Ru} . \mathrm{Fe})$ bond angles are gradually increased toward $180^{\circ}$. It is well known that in $\mathrm{La}_{2} \mathrm{CuO}_{.}$-related superconductors the $\mathrm{Cu}-\mathrm{O}$ Cu bond angle would straighten out to $180^{\circ}$. which would remove the mixed symmetry: ${ }^{9.11}$ Such a straightening results in an orthorhombic- to -tetragonal transition. and superconductivity vanishes in the tetragonal phase. As listed in Table 1 . c/a values continuously decrease with increasing Fe-substitution. i.e. 1.0063 for $\mathrm{SrRuO}_{3}$ and 0.9997 for $\mathrm{SrRu}_{1} \mathrm{Fe}_{6,5} \mathrm{O}_{3}$. which shows the appearance of tetragonal character in $\mathrm{SrRu}_{1-\mathrm{S}} \mathrm{Fe}_{\mathrm{k}} \mathrm{O}_{3}$ series. These interpretations are well coincident with the resistance results of $\mathrm{SrRu}_{1-x} \mathrm{Fe}_{x} \mathrm{O}_{3}$ series as shown in Figure 4.

\section{Conclusion}

The $\mathrm{SrRu}_{1-3} \mathrm{Fe}_{3} \mathrm{O}_{3}(0 \leq x \leq 0.5)$ solid solutions were prepared by typical solid state reactions. The XRD data indicate that $\mathrm{SrRu}_{3-x} \mathrm{Fe}_{2} \mathrm{O}_{3}$ are orthorhombically distorted $\mathrm{GdFeO}_{3}$ type structure with a space group Pruma. Particularly. the lattice parameters $a$ and $b$ gradually decrease with increasing Fe-substitution. whereas the lattice parameter. $c$ increases. The cla values continuously decrease with increasing $\mathrm{Fe}-$ substitution i.e. 1.0063 for $\mathrm{SrRuO}_{3}$ and 0.9997 for $\mathrm{SrRu}_{1} 5_{-}^{-}$ $\mathrm{Fe}_{1} \mathrm{O}_{5}$. which shows the appearance of tetragonal character

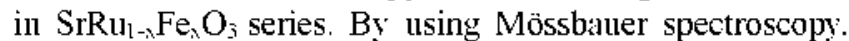
the valence state of iron in $\mathrm{SrRu}_{3-3} \mathrm{Fe}_{\mathrm{x}} \mathrm{O}_{3}(x=0.1,0.2,0.3$. 0.4 and 0.5 ) is determined to $\mathrm{Fe}(\mathrm{III})$. The Fe-substituted $\mathrm{SrRuO}_{3}$ has different bond lengths, in particular (Ru.Fe)-O $(\times 2)=2.00 \mathrm{~A} .(\mathrm{Ru} . \mathrm{Fe})-\mathrm{O}_{2}(\times 2)=1.92 \mathrm{~A}$. and $(\mathrm{Ru} . \mathrm{Fe})-\mathrm{O}_{2}$ $(\times 2)=2.0 \mathrm{l} A$ for $\mathrm{SrRu}_{1,3} \mathrm{Fe}_{15} \mathrm{O}_{3}$ compound. which notifies us that the $\mathrm{Fe}^{3 .}$ species create $\mathrm{Ru}^{51}$ species as the longer $(2.01 \mathrm{~A})$ and the shorter bond-length $(1.92 \mathrm{~A})$ exist in (Ru.Fe)-Oz sheets compared with those of $\mathrm{SrRuO}_{3}$. The (Ru.Fe)- $\mathrm{O}_{1}-(\mathrm{Ru} . \mathrm{Fe})$ bond angles are continuously decreased with increasing the contents of Fe-substitution. whereas (Ru.Fe)-Oz-(Ru.Fe) bond angles are gradually increased toward $180^{\circ}$. These structural behaviors are well coincident with the resistance results of $\mathrm{SrRu}_{1 \times \mathrm{S}} \mathrm{Fe}_{\mathrm{x}} \mathrm{O}_{3}$ series

Acknowledgment. This work was supported by Korean Research Foundation Grant (KRF-2000-015-DP0298).

\section{References}

1. Rama Rao. M. V: Sathe. V. G.: Somadurai. D.: Panigrahi. B.: Shripathi. T. Wounat of Phasics and (hemistry of Soldds 2001. 62. 797.

2. Gupta, A. Hussey: B. W.: Shaw: T. M. Materials Research Bulletin 1996, 31. 1463.

3. Maignan, A.: Martin, C.: IIervicu. M.: Raveau, B. Solid Stak Commmication 2001. 117.377.

4. Takano. M.: Nakayama. N.: Bando. Y.: Takeda. Y.: Kanno. K.: Takada. T.: Yamamota. O. J. Sol. State Chem 1986. 63. 237.

5. Shannon, R. D. ActaConst. 1976,32.751.

6. Demazeau, G.: Fabritchiny, P.: Foumes. I..: Darrace. S. Presniakov, I. A.: Pokholok, K. V. J. Water Chem. 1995. 5. 553.

7. Nasu. S. Hyperfine Interactions 1994. 90. 59.

8. Cao. X.: Koltypin. Yu.: Katabi. G.: Prozoror. R.: Felner. I.: Gedanken. A.J. Water ('he'm. 1997. 7. 1007.

9. Goodenough, J. B.: Manthiram. A.: 7.hon, J. Hat. Res. Soc Symp. Iroc. 1989, 156. 3399

10. Goodenough, I. B. ARS Bulletin 1990. May, 23. 